\title{
Decentralization and Education in Uganda
}

\author{
Immaculate K. Namukasa, the University of Western Ontario \\ Ronald Buye, Makerere University.
}

\begin{abstract}
Uganda is one of the African countries that have decentralized its education system. This country-specific paper examines the implementation process and the way forward to decentralizing education in a developing country. There have been gains and challenges from decentralization and processes linked to it. While the implementation of Universal Primary Education in 1997 increased significantly school enrollment as well as the number of classrooms; on the other hand, student-teacher and student-resources ratio also increased, and corruption and mismanagement of resources remained a challenge.

\section{Résumé}

Uganda est un des pays d'Afrique qui ont décentralisé leur système d'enseignement. Cet article spécifique sur un seul pays examine les processus d'exécution et la façon d'avancer la décentralisation dans un pays au cours de développement. Il y a des gains et aussi des problèmes provenant de la décentralisation et des processus qui l'accompagnent. L'application de la loi "Éducation primaire universelle" en 1997 a augmenté considérablement l' effectif des écoles et le nombre des classes mais le rapport élèves/instructeurs ainsi que celui entre élèves et ressources ont aussi augmenté, et la corruption et la mauvaise administration des ressources constituent encore des obstacles.
\end{abstract}

\section{Introduction}

Developing and developed countries are decentralizing their education systems. In some countries, especially developing countries, educational decentralization is part of a larger exercise of devolving all public services. In sub-Saharan Africa the factors that encourage centralization include positive effects such as political stability and economic development, as well as push factors like existing regional inequalities and inadequacies, real and perceived, of central governments. Multilateral and bilateral donor communities are encouraging countries in the South to decentralize and/or privatize public services. Among these countries Uganda has proceeded quickly in an almost all-at-once decentralization strategy (Naidoo, 2002; Steiner, 2006).

In Uganda, decentralization is not totally new. Regional governments mainly in the form of monarchies and chiefdoms were abolished in 1966, four years after independence (Mushemeza, 2003). The post independence constitution of Uganda, laid a legal framework for re-decentralization based on regional 
governments but this never took off. The current Ugandan government administered some decentralization in the areas under its control in the early 1980s while it was still a guerilla force called the National Resistance Army (now a political force called National Resistance Movement). After it came to power in 1986, the government adopted country-wide decentralization, cost sharing and privatization as policies supported by multinational donor agencies such as the World Bank and the United Nations Development Programme (UNDP). To date most government-administered services (except a few, such as the police and the army) that have not yet been privatized are decentralized. These include primary healthcare, education, basic services in water and sanitation, feeder roads and agricultural extension. Decentralization has changed the delivery of public services, particularly education.

Education has been decentralized to local governments beginning with primary (an equivalence of elementary) education. Many programs have been put in place to facilitate decentralization of education service delivery. It appears that the decentralization of education has been more effectual at the elementary level than at other levels.

In the context of Uganda, decentralization is taken to mean the reassignment of some decision-making (management) authority, responsibility and tasks from the central government to local governments. Legal, financial, administrative and political management of public functions has become the responsibility of the local community, under the leadership of Local Councils (LCs). Decentralization appears to be based on the governance idea of subsidiarity: matters should be handled by the smallest (or lowest) authority. Subsidiarity means that a central authority should have a subsidiary function, performing only those tasks which cannot be performed effectively at a more immediate or local level. Central authorities delegate management to sub-national, municipal or local units (Naidoo, 2002). There are varying degrees to which this delegation happens, ranging from deconcentration at the lower end, through delegation, to devolution at the upper extreme. To some scholars and some multilateral organizations such as the World Bank, privatization is a form of devolution (Hanson, 1998; Suzuki, 2002; UNESCO, 2004).

Deconcentration involves the spatial relocation of decision-making; some administrative responsibility is transferred to lower level governments. Because it is the lowest form of decentralization, deconcentration, also referred to as administrative decentralization, involves the transfer of tasks and responsibility but not of authority (Hanson, 1998; Naidoo, 2002; UNESCO, 2004).

Under moderate decentralization-delegation - the transferred decisionmaking authority may be withdrawn from the local government at the discretion of the central unit. Delegation involves the transfer of fiscal and administrative tasks but not of political tasks.

When the highest degree of authority, which includes political and market responsibility for governing, is transferred to the local government devolution is said to be taking place. Devolution involves the creation or strengthening, financially or legally, of sub-national units of governments. Naidoo

94 Canadian and International Education Vol. 36 no.1 -June 2007 
(2002) compares the status of education decentralization in six sub-Saharan African countries including Tanzania and Ghana. He identifies Uganda as the only example of devolution. Devolution of education is political and financial (UNESCO, 2004). It goes hand in hand with the introduction of market forces to the system through privatization. In Uganda elementary education was universalized in 1997. Plans are underway to universalize secondary education in 2007. With the case of devolution, it is crucial to asses the risks of shedding financial responsibility to local governments and to communities.

\section{Historical Considerations}

The Ugandan education system was one of the best in Sub-Saharan Africa (Odaet, 1990; Ssekamwa, 1997). During the economic and political instabilities it was resilient to the inadequacies of central government (Heynman, 1983; Paige, 2000) and to political and economic difficulties that ensued. As in other former colonies, Christian missionaries introduced formal schooling in Uganda decades before British control over Uganda was signed in 1890. Missionaries and other foreign groups such as East Indians were in charge of founding, administering and funding schools (Odaet, 1990). Local Ugandans, mainly traditional chiefs had a role, in the spirit of self-help, to provide building materials, land and labor (Ssekamwa, 1997). The willingness of communities to contribute in cash and kind is a traditional strength of education in Africa. The missionary-founded schools were built on various Western models of education. A majority of these schools had coherent structures and strong religious traditions. The missionaries supplied human resources, adopted curriculum and provided textbooks and equipment. It is after one of the traditional kingdoms, the Kingdom of Buganda became a British Protectorate that all schools became the domain of the British Empire, with English as the official language of instruction (Odaet, 1990). But the colonial government did not yet involve itself in establishing, financing and administering schools.

Around 1920, the Uganda protectorate government gradually began to assist the missionaries in the provision of education. The central government began constructing public schools and aiding schools with grants. In 1963 the Education Act was passed to place all grant-aided schools under the control of the government. This progressively curtailed the control of schools by racial and religious bodies, but major differences remained among schools founded by different bodies.

In 1970 a second Education Act was introduced to encourage the establishment of private schools in Uganda. This act streamlined the requirements and procedures for establishing and operating a private school (Ssekamwa, 1997). A few more church-founded schools and a couple of international schools were established. Private colleges were also established. Most education policy and planning commissions and reviews, prior to and after independence in 1962, recommended more support by central government for academic secondary schools and tertiary institutions. Smyth (1970) explains that secondary education was seen to enhance economic development and was seen as a way of increasing 
the number of Africans in responsible positions-Africanization-that was urgently needed with independence inevitably coming. The most support for expansion that primary schools got was indirectly through increased output of new teachers from existing training colleges. Many primary schools lacked some of the basic facilities particularly textbooks and equipment.

Since the end of the war a couple of national education plans have shaped the education system of Uganda: the 1987 Education Policy Review Commission (EPRC) which reported on the state of the system of education after the political, military and economic turmoil of 1970-1980's. The EPRC made recommendations including change in focus to accommodate the long held desire of basic primary education. It underscored the role of science and mathematics for national development and social transformation. The Education Bill (2000) revised and updated the 1970 Education Acts and provided for a more contemporary framework. With the post war government many changes in the Legal framework took place including The National Constitution for the Republic of Uganda that underscored education as a right of every Ugandan, and the Republic of Uganda Local Government Act (1997) that transferred Primary and Secondary Education services to Local Governments at the district level-- an example of decentralization of education delivery. Many programs have been put in place to facilitate decentralization of education service delivery, including: the Education Strategic Investment Plan (ESIP); Universal Primary Education (UPE); School Facilities Grant (SFG); Teacher Development and Management System (TDMS). In 1997 elementary education was universalized beginning with grades 1 to 4 .

The growth of private schools had been slow until the late 1990s. Several factors caused private education to grow exponentially in the late 1990s. These include economic and political stability; further, recovery from war increased school enrollments and Universal Primary Education (UPE). Many schools are now owned by individuals or groups of persons. In 2005, there were 11,850 Government aided and 1,521 Private primary schools. There were 1651 Government aided secondary schools and about 1898 private secondary ones (Bitamazire, 2005). Clearly at the post-primary level the private sector is over taking the public sector in education provision. This is without implications for the curriculum delivered. Private schools for children from middle-class and affluent families are better-equipped and staffed with more affluent teachers. There are also many impoverished private schools for students of low socioeconomic status and/or with low academic achievement. These schools are poorly-equipped and staffed with ill-paid teachers in order to keep the tuition affordable for parents. Before Universal Secondary Education (USE) is implemented there will be a steady growth of private secondary schools that survive on meager resources. Very few public schools have been built even at the secondary level where there is increasing need. With the commercialization of higher education, private universities and colleges have emerged to supplement what used to be exclusively publicly-funded tertiary education. Efforts towards expansion and improvement of technical institutes are also limited.

96 Canadian and International Education Vol. 36 no.1 -June 2007 
Decentralization of the Ugandan education system is closely linked to other education reforms including the universalization of basic education, growing privatization and commercialization of higher education (Naidoo, 2002; UNESCO, 2004)

Education decentralization in Uganda was not an educational reform, as it was in other countries such as Sri Lanka and Australia. The Ugandan process of decentralization, devolution of primary education, was mainly driven by national political will rather than by educational reform (Stasavage, 2005). This meant that legal frameworks of decentralization in general were helpfully modified and made compatible with those of decentralization in education.

\section{Decentralizing Administration}

In 1986, the National Resistance Movement government put in place a new system of local governance at first called Resistance Councils, another sign of a political form of decentralization. Resistance councils were later renamed Local Councils (LCs). The LC system is a five-level tiered system. It progresses from the zone (village) level (I), through parish (II), sub-county/division (III), county/sub-district (IV) and district/municipal (V) to the central government level. The first phase of the LC I to LC V tiered local governance was launched in 13 (out of the then 45) districts. Councils at lower levels have nine five-yearly elected councilors including a chairman, vice chairman and secretaries representing women, youth and security. Starting from LC III going up to LC V, the councils are administrative bodies in addition to being political and legal bodies. LC III is headed by the sub-county chief in rural areas and by town clerks in towns. The district administration, LC V in the capital city is headed by the mayor; elsewhere it is headed by an administrative officer. Councilors, especially at the lower levels, are unpaid volunteers. ${ }^{1}$ Starting at LC II going up to the district, the service commission recruits and remunerates administrative personnel like sub-county chiefs and parish council agents. In 1993 the Local Government (Resistance Councils) Statute was passed to provide for the transfer of powers and resources to Local Councils.

Currently the broader decentralization process in Uganda is guided by the 1997 Local Government Act. With this Act, Resistance Councils were renamed Local Councils (LCs). Education was listed as one of the major public functions for which the highest level in the local hierarchy, the District council, was to be directly responsible (Local Government Act, 1997, Article 176(2) of the Constitution, Section $97 \& 98$ ). In the Act the levels of education that were to be decentralized were listed as nursery, elementary, secondary, trade education, special education and technical education. Higher and university education continued to lie outside the governance of local councils. The objectives of the Act were to:

- give full effect to the decentralization of functions, powers, responsibilities and services at all levels of local governments;

- ensure democratic participation in and control of decision making by the people concerned; 
- establish a democratic, political and gender-sensitive administrative set-up in local governments;

- establish sources of revenue and financial accountability; and

- provide for the election of Local Councils.

\section{A Centralized Education System}

Before decentralization, all systems were centralized under the national government and the district/municipality governments. The districts implemented policies chosen by the central government. They carried out activities on behalf of the ministry of education. Key personnel included the Permanent Secretary and the national Chief Education Officer (CEO) at the national Ministry of Education level, and the District Education officer (DEO) at the district level. Ssekamwa and Lugumba (1973) observe that during that time the key person who administered elementary schools' educational service in any district was the District Education Officer (DEO). With the assistance of one or two assistant inspectors of schools attached to his office, the DEO advised elementary school head teachers. The DEO was, on behalf of the national Chief Education Officer (CEO), responsible for the inspection of elementary schools, in-service teacher education, professional development workshops and courses, transfer of teachers, and the administration of grants for school buildings, equipment, furniture and funds for elementary school teachers' salaries. The DEO was answerable to the Permanent Secretary.

The two-tiered centralized governance of education posed a problem for districts far away from the main national administrative city, Kampala. Worse still, many local areas were far from their district headquarters. Personnel at the district level were limited. The unequal access and other inequities were aggravated by political instability and the economic difficulties of the 1970s and 1980s. At many times local plans could not be fully implemented because no particular unit-district or national-was responsible. There was also a widespread lack of key competent and skilled personnel. Other factors such as lack of training and capacity-building, along with growing divisions along tribal and regional lines also contributed to the inadequacy of centralization. The new government proposed decentralizing governance of public services as a panacea for all these challenges.

\section{Objectives of Decentralizing Uganda's Education}

The government of Uganda perceived many benefits of decentralizing educational governance. It conceived that decentralization would: (a) eliminate what it saw as unnecessary bureaucratic channels, (b) reduce corruption by minimizing the number of office levels to be consulted, (c) boost the level of monitoring since there would be physical proximity of local governments, (d) result in the management of the education system according to local priorities (e) improve financial accountability since local people and personnel would be motivated to monitor local governance, and (f) raise local revenue to fund services. 
In 1998 the government embarked on strengthening the decentralization system in order to improve the management and delivery of elementary education services. This also illustrated a shift in roles, from deconcentration to devolution. The districts ceased to be mere implementers of central government policies. The district staff base was expanded beyond supervisory roles to engage in spending, accounting, planning, budgeting, monitoring and evaluation. They now receive capitation grants from the central Ministry of Finance and Economic Development (MoFED). These funds are spent and accounted for according to guidelines provided by the national Ministry of Education and Sports (MoES). District councils also prepare district capacity-building plans and budgets. Each district, as a member of the national education planning process, prepares sector plans for district capacity-building. They draw plans such as for classroom construction and resource acquisitions that have to be approved by MoES. These district plans and budgets increasingly contribute to the central MoES planning and budgeting.

Since educational decentralization was part of a wider political reform, it is unlikely that careful thought was given at the planning stage to far-reaching educational implications of decentralization and to how it would be interpreted in practice. It appears decentralization laws preceded workable models of decentralization. Although phasing in decentralization allows for experimentation and the possibility of revisions, Uganda chose the all-at-once strategy. All districts took responsibility of their education systems, whether they were ready or not.

\section{Post-Decentralization Ugandan Education System}

Although decentralization was phased in quickly at the regional level, at the school level decentralization appears to have proceeded more slowly. For elementary schools the District government is the highest point of reference and authority. Local authorities have financial control and general decision-making powers over elementary schools. The schools are accountable, through the subsequent levels of governance, to the Education Committee headed by the District Education Officer (DEO). This system of power-sharing has made decision-making quick and easy. But one wonders about the challenges that come with easy and quick decision-making in a developing system. At times decisions about education issues are made by personnel who have little experience in education governance. The success of decentralization depends on the question: How have education policy makers addressed the challenges that come with local governance in a country where resources are neither adequately nor evenly distributed? One way has been to strengthen both the central and local administrative infrastructure in support of educational decentralization.

\section{The New National Governance Structure}

In 1998 the Ministry of Education underwent post-constitutional restructuring. The central government began strengthening infrastructures and institutions at MoES. Many new national institutions were created and many roles were decentralized to districts. Central government now concentrates more on planning, 
policy analysis, curriculum and examination reform, national assessment, and monitoring and evaluation. Before decentralization three semi-autonomous institutions existed: National Curriculum Development Center (NCDC); Uganda National Examinations Board (UNEB); and National Council for Higher Education (NCHE). Under the new structure, as shown at the bottom of Figure 1 (page 101), the MoES is comprised of eight departments for planning and policy analysis; a commissioner heads each department. A policy analysis unit, a resource centre, and three technical units (procurement, construction management and instructional materials) were established. In addition to institutions that existed before, there are six semi-autonomous institutions (see left of Figure 1, page 101) that have been established to handle more specialized functions of the Ministry. These include Education Standards Agency (ESA), Education Service Commission (ESC), Uganda National Council for UNESCO. Many activities are coordinated by multiple units, institutions and departments.

No institution was eliminated: NCDC and UNEB still exist, and NCHE was transformed into a department and two institutions. Many activities are coordinated by multiple units, institutions and departments. For example, to review the curricula, the government set up a task force that involved different actors mainly at the Ministry. MoES outlined its aspirations for the new curriculum before forwarding the responsibility to the NCDC (MoES, September 2003). Evidently, support structures with defined roles are in place to support the implementation of decentralization of education. For instance, ESIP is responsible for building the capacity of district and local governments effectively and efficiently to deliver public educational services and to assure the quality of privately delivered services. The TDMS program is intended to improve quality and equity in the provision of elementary education through improved teacher training, development and professional support.

In the process of building local devolved systems centralized bureaucracies were strengthened. Strong central regulation in such areas as curriculum design, assessment, teacher development and higher education remained. This is not surprising for a country where political and economic motives were central to decentralization. Naidoo (2002) dubs this a case of intense state control of some functions being coupled with greater decentralization of other aspects. It is centralized decentralization. The co-existence of both processes is very supportive but is not without contradictions. It is likely to produce lived tensions for school principals, teachers, parents and the local community.

\section{New District Governance Structure}

At the district level some institutions were created to support the office of the DEO. With decentralization, key personnel in the district include: the Chief Administrative Officer (CAO), who is the district accounting officer, and the District Inspector of Schools (DIS), whose work is more pronounced at the elementary level. The District Education officer (DEO) remains the head of the 
education department and Education Committee at the district to whom the head teachers (school principals) are answerable.

Figure 1. Structure of Central Education

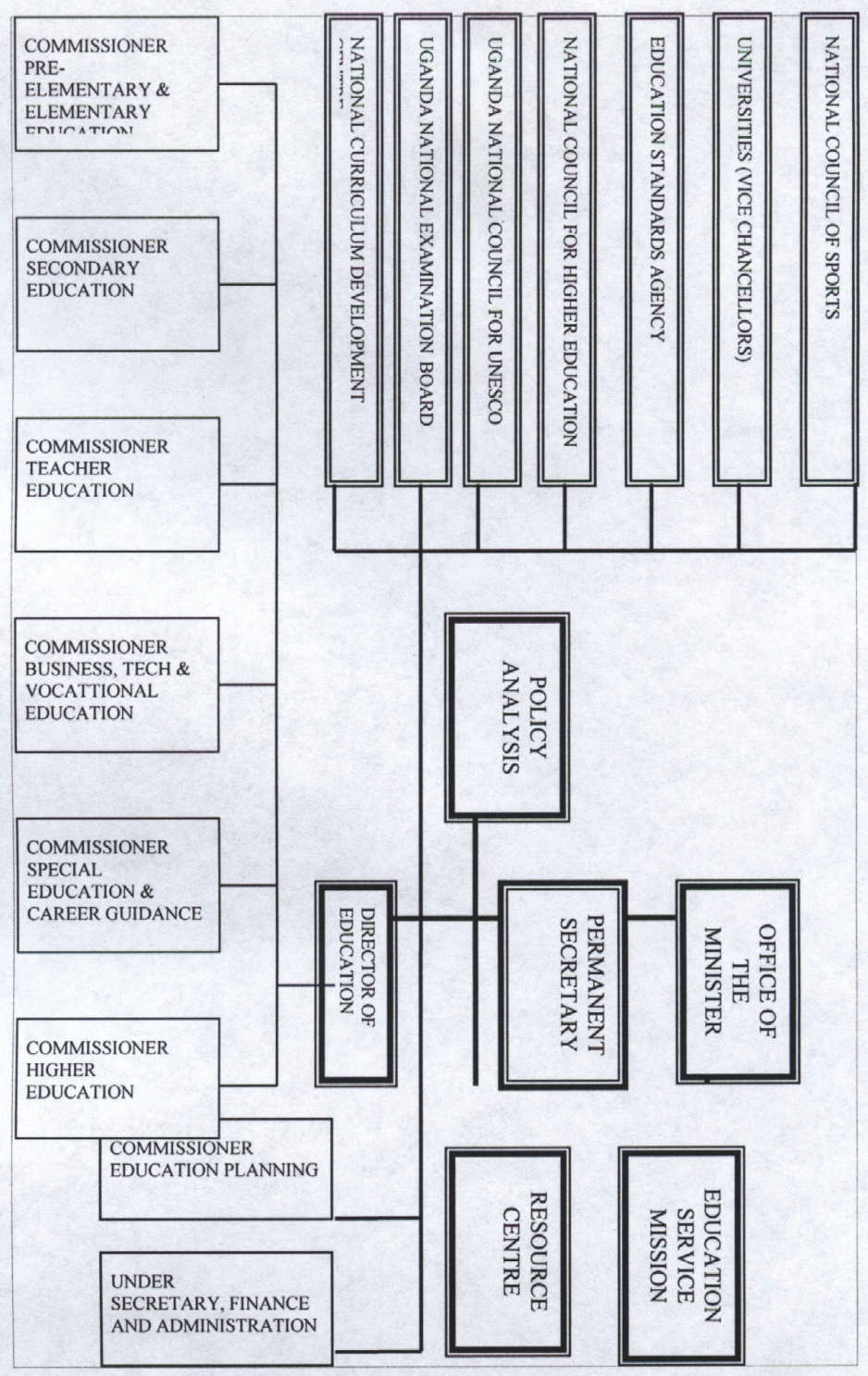

Education canadienne et internationale Vol. $36 \mathrm{n}^{\mathrm{o}} 1$-juin 2007101 
All the district education staff and institutions, including the DEO, operate under the control and supervision of the CAO. The CAO is an appointed member to the tier V District Local Council (DLC). The DLC is the main budgetary unit in the district. The DEO is now directly answerable to the CAO, whereas in the past the DEO was answerable to the Permanent Secretary at the Ministry of Education. The DEOs are responsible for monitoring and supporting all schools within their districts, and they work with the CAO to develop plans and budgets. Through the District Service Commission (DSC), each district recruits and assigns elementary school teachers, as they do other public servants. The $\mathrm{CAO}$ receives funds for education in the form of school staff salaries, funds for school supplies and grants, which are dispatched to principals through the DEO. From the time elementary education was universalized the central government has been responsible for funding elementary education under the UPE program.

Elementary schools report to the DEO and receive communication from the District Headquarters, but secondary and tertiary schools still primarily report to the Director of Education at the central government who then is answerable to the Permanent Secretary. By law, finance and administration are decentralized for elementary, secondary, and technical levels (Wamala, 2004). In practice, the shift in roles for the MoES from delivery of education to policymaking, investment management, and quality assurance is only at the elementary education level. Policy, budgeting and planning for secondary schools are not yet decentralized. This might be interpreted as a form of phased-in decentralization or as a selected focus at one level at the expense of the other. In secondary schools it is mainly the salaries of teachers and the capitation grant that are channeled through the decentralization structure. Other issues regarding secondary education, such as the recruitment and transfer of teachers, remain the responsibility of the ministry. As regards inspection, there is ambiguity as to whether the District Inspectorate staff has anything practical to do with secondary schools. There is also a question about whether these staff are qualified enough to inspect secondary schools. Decentralization has had almost no effect on pre-elementary/kindergarten education and day care. This level of education remains in the private sector.

\section{Financial Decentralization}

In many Latin American and Caribbean countries educational administration has been decentralized. Educational finance has also been decentralized, but to a lesser extent. In Uganda financial decentralization is in the lead.

Through financial decentralization, education grants are calculated centrally and then released to the districts as conditional, non-conditional or equalization grants. Equalization grants are paid to local governments for giving subsidies or making special provision to the least developed districts (Local Government Act, 1997, section 84(4)). Conditional grants are budgeted for as capitation grants that are distributed to the schools in accordance with their enrolments. UNESCO (2004) suggests that school formula funding, based on enrollment, location and the like, can reduce the opportunities for corruption.

102 Canadian and International Education Vol. 36 no.1 -June 2007 
Capitation grants are spent on instructional and scholastic materials, on cocurricular activities, on school management and on administration. Whereas a number of these are donor-specific initiatives, elementary teachers' salaries, classroom construction, school capitation grants, support for the Teacher Development and Management System (TDMS), and funds for instructional materials are provided through a special programme, the general Poverty Action Fund (PAF). The PAF is the main source of financial support to elementary education. Currently, about 75 percent of the total PAF transferred for education and 72 percent of all government resources for education are provided through the districts (USAID, 2000).

Among conditional grants are a variety of special expenditures aimed at supporting the curriculum: the School Facilities Grant (SFG), teacher salaries for elementary schools, UPE grants, and the Instructional Material Grant (IMG). The ministry sends funds for secondary school teacher salaries to schools through the district whereas salaries for elementary teachers are part of conditional grants that the district receives from the central government. The SFG supports communities' efforts to improve the accessibility and quality of elementary school education. The target is to achieve better classroom facility ratios, which include a teacher-pupil ratio of 1:55, a desk-pupil ratio of 1:3, a latrine-pupil ratio of 1:40 and at least four teachers' houses per school (MoES fact file, 2003). The UPE capitation grant provides less than $\$ 10$ per child per year for children who are in their first three years of elementary education. UPE grants and the IMG are aimed at providing adequate quantities of good quality instructional materials. The CAO receives and ensures the prompt disbursement of education grants to schools. The $\mathrm{CAO}$ accounts for these funds in a proper manner, and ensures that conditional monies such as the UPE grants are not diverted to other needs. Diversion of funds, especially at the school level, is a common challenge.

Provision of infrastructure involves many activities and actors. Major activities include planning, budgeting, release of funds, accounting, reporting, monitoring and evaluation. These activities are done at the different levels: school/local community; sub-county, division, district, MoES, and by other concerned actors such as MoFED and the President's office.

The involvement of the local community that originally occurred through the Parent Teacher Associations (PTAs) now takes place through the School Management Committee (SMC). SMCs include 7 appointed members and only two members elected by parents (Suzuki, 2002). SMCs are not unique to Uganda. They were established in Mali as well. In Uganda, SMCs and PTAs co-exist with varying powers; the former is responsible for UPE grants. These committees oversee school administration, development and improvement projects. The SMC is intended to be the increasingly empowered governance mechanism dealing with education locally.

The unique structures through which centralization has been strengthened and decentralization implemented appear beneficial. Devolution, the higher extreme of decentralization, is said to have a low risk of long-term failure. The layered structures defined above may nevertheless present great risks for the Ugandan education system. 
Decentralization has been practiced for almost a decade in Uganda, longer than many countries in Africa. In the next section, we draw on the literature on decentralization to theoretically tease out strong aspects and weak points of the Ugandan education decentralization process. Even though no experimentation phases were built into the process, analyzing the benefits and risks of the implementation structures is likely to allow Sub-Sahara African countries to learn from the experience of others at decentralization. Where professional will is led by political will there are likely to be large gaps between proclaimed policies and implementation practices. Uganda can learn from countries such as Spain and Nicaragua where educational reform policy, not national law, guided the process. For Caribbean and Latin American countries where national law guided the decentralization reform such an analysis will help policy makers to assess the benefits and risks of decentralization work as an educational reform.

\section{Benefits}

The education sector in Uganda has changed dramatically over a period of ten years. The most notable change is in access to primary education. In 1992, 2.4 million children enrolled with a gross enrolment ratio (GER) of 68 per cent and a net enrolment ratio (NER) of less than 40 per cent. Today more than 7 million children are enrolled, the GER is over 120 per cent, and the NER over 80 per cent. There have also been significant changes in the number of and proportion of trained teachers, the classrooms built and available and the textbook purchase and distribution system. The implementation of the UPE program has meant an increase in resource flows from higher government in terms of grants, materials and construction funds. (Murphy, 2005, p. 139)

Grade 1 Gross intake rate and Primary level gross enrolment ratio (see table 1) are the most commonly used statistics when illustrating the benefits of decentralization. Many funding agencies are more comfortable dealing directly with specific Ministries and with local communities. The central and local administrative infrastructures as well as primary school and private secondary school infrastructures are stronger today than they were before decentralization (Deininger, 2003). Some least-developed districts such as Kalangala are benefiting from the equalization grant. Community involvement in decisionmaking is encouraged through school level policy-making by the school management committee and local councils (Suzuki, 2002). A detailed analysis of the Ugandan reforms shows that in fact some sub-county government officials are well aware of the preferences of parents. 
Table 1. Uganda Education Data

\begin{tabular}{|c|c|c|c|c|c|c|c|c|}
\hline & 1985 & 1990 & 1995 & 2000 & 2004 & 2005 & $\mathrm{SSA}^{\mathrm{a}}$ & $\begin{array}{l}\text { Low } \\
\text { income } \\
\text { SSA }\end{array}$ \\
\hline $\begin{array}{l}\text { Surface area }(000 \text { 's } \\
\text { Sq.Km) }\end{array}$ & b & & & 241 & 241 & 241 & & \\
\hline $\begin{array}{l}\text { Population total } \\
\text { (Millions) }\end{array}$ & & & & 24.3 & 27.8 & 28.8 & & \\
\hline Per capita GNI (US\$) & 190 & 320 & 230 & 260 & 250 & & 607 & 507 \\
\hline Adult literacy rate ${ }^{\mathrm{c}}(\%)$ & & 56.1 & & & 66.8 & & & 61.7 \\
\hline Primary level GER ${ }^{\mathrm{d}}(\%)$ & 73.2 & 68.7 & 74.3 & 127 & 125 & 118 & 93.1 & 104.4 \\
\hline Secondary level GER (\%) & 10 & 12.5 & 12 & 15.9 & 18.6 & 16 & 29.8 & 45.2 \\
\hline Tertiary level GER (\%) & 0.8 & 1.2 & 1.7 & 2.5 & 3.4 & & 5.6 & 9.1 \\
\hline $\begin{array}{l}\text { Grade } 1 \text { Gross intake rate } \\
(\%)\end{array}$ & 88.7 & 107.8 & - & 172.7 & 163.5 & - & 109.8 & 122.3 \\
\hline $\begin{array}{l}\text { Primary completion rate } \\
(\%)\end{array}$ & & & & 58.2 & 57.1 & & 61.1 & 77.8 \\
\hline $\begin{array}{l}\text { School life expectancy } \\
\text { (years) }\end{array}$ & & & & 10.6 & 10.4 & & & 9.7 \\
\hline $\begin{array}{l}\text { Progression to secondary } \\
(\%)\end{array}$ & & & & 40 & 36.2 & & & \\
\hline Repetition rate $(\%)$ & & & & 2 & 1.9 & & & 5.1 \\
\hline $\begin{array}{l}\text { Primary pupil-teacher } \\
\text { ratio }\end{array}$ & 34.5 & 28.5 & 35.2 & 52.7 & 50.1 & & 50.3 & 42 \\
\hline
\end{tabular}

Sources: World Development Indicators database, April 2006

http://devdata.worldbank.org/edstats/SummaryEducationProfiles/CountryData/G etShowData.asp?sCtry=UGA,Uganda

Notes. ${ }^{\mathrm{a}}$ SSA stands for Sub Saharan Africa. ${ }^{\mathrm{b}}$ Blanks represent unavailable statistics. ${ }^{\mathrm{c}}$ Literacy rate, adult total (\% of people ages 15 and above). ${ }^{\mathrm{d}}$ GER stand for Gross Enrollment Ratio.

They fulfill them when institutional rigidities do not prevent them from doing so (Steiner, 2006). In many schools, especially the missionary-founded schools and boarding schools, there was previously a lack of community involvement. With most administrative roles retained by the ministry and the district, and plus with a majority members of the SMC appointed by the central and local governments the perceived benefits of decentralization might not come to pass (Suzuki, 2002); for example, SMC's minimized participation of and accountability to parents. As well, increased community participation may not necessarily result in increased choice and diversity. 
Diversion of funds, irregular payments and decayed arrears plagued the education system into the late 1990s. Because of corruption among officials and slackened management measures there were chronic inefficiencies in transferring teachers' salaries from the central government to district governments and then to the schools. Even getting new teachers appointed, posted and then enlisted on the payroll took years. Teachers would teach for years before they got their first salary. Salaries were terribly low. Salary arrears accumulated and some were written off after decades. Some teachers quit the teaching profession to try alternative means of survival;, others taught at private schools in addition to the public schools where they were posted. In rural areas many teachers took on casual labor jobs, opened up kiosks, or farmed to supplement their incomes. PTAs attempted to fill the gap by remunerating teachers and funding schools. This escalated the inequalities among schools, as parents of some schools were middleclass. Also this lowered the teacher's professional status as parents became employers of teachers. Government attempted to abolish PTA fees and to curtail PTA responsibilities at the school but these efforts were unpopular among both parents and schools (Al-Samarrai, 2003)

With the devolution of responsibility for elementary education to the district level, teachers' salaries are now paid more promptly and the management of the payroll has improved. District administrators can manage their funds without being slowed down by the bureaucracies of the central government. Elementary school teachers are appointed, posted and remunerated over a period of no more than six months. (This is not yet the case for secondary school teachers, who suffer a recruitment freeze and are still appointed centrally.) Remitting teachers' salaries through banks circumnavigates the diversion of salaries and other risks involved in cash payments. Prompt remuneration undoubtedly reduces teacher burnout, increases teacher retention rates and boosts teachers' motivation and status in the community (Saito, 2000).

Gershberg (2003) notes that information on the conditional grants to districts is published in the national press and provided to schools. This acts as a measure for increased accountability and transparency. District headquarters are required to display publicly the amount of UPE funds received and how they are planning to allocate them. Schools and sub-counties, in turn, must publicize their budgets and sources of funds. Monitoring and evaluation measures are put in place at all levels. The technical assistance units support the move from control to efficiency that came with decentralization. Further, there appears to be structural collaboration among major national institutions such as the Planning, Local Government and Education Ministries, along with the President's office.

\section{Administrative Risks}

Geographic decentralization in Uganda has involved both existing districts and new districts created by the process. Many existing districts had some form of infrastructure, revenue and power. Thus the devolution process was somewhat supported. However, some existing problems of administrative weakness and inequity were imported into the new system. Even when the government has invested a lot of funds in infrastructure, there is a chance that weak and new 
districts might be run on informal and personal principals such as whose child are $y o u$, and that rules may be poorly followed and policy implemented less rigorously. This has been the case for developing countries in Latin America. The same is true in Uganda. Preparing new districts to take on their responsibilities goes beyond preparing the physical infrastructure. Readiness checks need to be put in place to ensure sufficient trained personnel along with financial and community participation at the local level.

It may appear more equitable to decentralize all regions at the same time and at the same pace. However, this method assumes that decentralization does not require a foundation. No time is allowed for experimentation and adjustment. Weaker and new districts do not get the opportunity to learn from stronger districts. Hanson (1998) warns that all at once decentralization may send a country into some form of chaos for the implementers. Even Spain, a developed country, implemented its decentralization program in phases.

Privatization and support for private schools introduce new choices and diversification. Some schools, especially those that claim to be international, follow non-Ugandan policy and have their students learn non-Ugandan syllabi such as the Cambridge syllabi. With the establishment of over twenty new departments, institutions, programs and technical units, tools to safeguard the national educational policy appear to have been strengthened. As in Spain, decentralization is not likely to fragment the education system in Uganda because a lot of policy-making is still done at the national level. However, there is little chance that diversity and choice in schooling will be achieved. The national educational policy, school curriculum and syllabus frameworks, national assessment, teacher training and associated resource materials are still the ministry's responsibility.

Teacher education, especially in-service teacher education for administrators, teachers and participating community members, has been catered for by the Teacher Development and Management System (TDMS) and in the districts. Whether this professional development is taking into account the changing personal and professional needs of a decentralized system such as group dynamics, negotiation and public relations is a question that needs empirical study. In a USAID (2000) report it was noted that the quality of teaching and learning suffers from weak leadership and an irregular flow of resources.

Decentralization aggravates needs for intensive, continuing training including financial training for administrative and educational personnel as well local authorities and parents (UNESCO, 2004). Strengthening leadership and management of a decentralized education system requires work not only at the district level but at the sub-county and even the parish levels. Strategies are complicated, entailing not only training in technical skills such as budgeting and data monitoring, but also higher-level skills such as political leadership and crossinstitutional collaboration. The number of districts whose capacity is inadequate for the tasks at hand multiplies the challenge.

With both decentralization and centralization occurring simultaneously there is likely to be duplication of duties and resources. In a country where monarchy governments existed before centralization, one would hope that 
decentralization would be synonymous with federalization. Instead, in Uganda cultural monarchies and decentralization uniquely run parallel to each other. In tribal regions such as Buganda, which have relatively cohesive kingdoms, there is tripling of systems: centralization, decentralization and federalization in the form of restored monarchies (Stasavage, (2005). Some duplication of resources has created depressing lived experience for teachers and students. One example is the introduction of district examinations for candidate classes. Learning and teaching now have to fit into the schedule of the regular school examinations, the district examinations and the final national examination. At the school level this is turning teaching and learning into an examination-focused practice.

Gershberg (2003) argues that devolution produces centralization at the regional level, in part because sub-regional responsibilities might not be well articulated in the decentralization legislation. This is particularly negative where regional officials are found to be less in touch than national officials with citizen preferences. The emergence of centralized districts is a growing issue in Uganda. Worse still that the districts at times are out of touch with what happens at lower levels does work against the assumptions of decentralization. With core education decisions around curriculum and school issues still centralized either at the national or district level, local community participation is still very limited.

Decentralization expanded the overall size of the bureaucracies to include LCs. This expansion does not necessarily imply an increase in efficiency. There is evidence that bureaucratic delays and centralized inadequacies have been curtailed by decentralization, but corruption seems to have multiplied. This is more limiting as corruption and non-professional management are now occurring at a minimum of three levels of governance: national, district and sub-county.

Some combined advantages of decentralization and centralization are equitable allocation of resources and programmatic unity. These may be offset by diseconomies of scale, as seen in many Latin American countries. For a country with such a small national budget, subdividing it at sub-national levels inevitably increases administrative costs.

\section{Financial Risks}

Funding criteria need to be looked into. Payrolls with ghost teachers and accountability data with ghost students and resources are commonly reported in the local Ugandan press. Local finance management has created monitoring loopholes. Formula school funding is facing limitations of misreported needs. A common mismanagement method is to inflate the number of pupils in order to receive more funds. The reason why this malpractice continues unchecked is that correct data is not available (Royal Netherlands Embassy, 2003). The Ministry of Education collects data annually through the Educational Management Information System (EMIS). Due to misreporting, it is difficult to gather and aggregate educational statistics. In September 2003 the District Service Commission Secretary of a new district, Kiboga, was remanded for putting "ghost teachers" on the payroll (Royal Netherlands Embassy, 2003).

Corruption grows. Corruption has been witnessed in the process of transferring ferring finances from the central government to local governments.

108 Canadian and International Education Vol. 36 no.1 -June 2007 
It is not rare for funds budgeted for one use to be diverted to another. Some resources have been diverted. In the Gulu district, for example, part of the Ush 2.6 billion (approximately 1.4 million USD) meant for elementary teachers' salaries was diverted in the financial year 1998- 1999, and another part was embezzled. Also funds for classroom construction were robbed during transportation. Districts such as Gulu have problems of accounting for their School Facilities Grant (SFG) fund (The New Vision, 23 August 2003).

Construction, resource and salary funds are misappropriated or their release to beneficiaries is deliberately delayed. Decentralization creates new avenues for corruption. Corruption is tiered when deeper and systemic reasons for corruption in developing countries are not addressed. Education funds sometimes end up in private accounts of local government officials where they earn interest for the officials. At the school level, head teachers are usually responsible for malpractice, delay or nonpayment of wages, misappropriation of grants and outright theft (Royal Netherlands Embassy, 2003). Corruption of all typesbribery, fraudulent reporting of data, shirking by employees, misuse of funds (UNESCO, 2004) - is taking place. Corruption, when it takes place in the education system, threatens the moral fabric of society.

Different key stakeholders at various levels carry out monitoring activity for capitation grants. At the district level monitoring and evaluation measures are put in place by the many ministries as well as by the President's office. Ministry of Education officials visit the district at least every two months to verify compliance and to appraise the district progress in the SFG implementation. The district monitors and evaluates the performance of schools and contractors. Monitoring is done at the school level by the District Inspector of Schools. The LCs and the SMCs do daily monitoring and evaluation of contractors and of the schools as well. But this local monitoring is weakened by high adult illiteracy rates (see Figure 1, page 105), lack of interest and lack of knowledge (Suzuki, 2002) The monitoring level is evidently retroactive and therefore needs to be supported with other proactive measures

In relation to procurement, the School Facility Grant (SFG) is plagued by corruption in the Classroom Construction Program (CCP). Although primary schools have little capacity to plan and account for expenditures, the schools are responsible for selecting and overseeing local contractors, with the assistance of the district assistant engineer and other district personnel. Schools are responsible for applying the funds, hiring a suitable contractor, supervising the work, paying the contractor, and ensuring the maintenance of services delivered. In 2001 an SFG evaluation was done. Different construction elements, such as doors and roofs, were monitored for their quality. The outcome of the quality evaluation showed that out of 35 classroom projects only 14 showed no shortcomings. On September 3, 2003, it was stated in a Special Audit Report from the Auditor General's office that out of Ush [Uganda Shillings] 238m remitted to the Gulu district for the Schools Facilitation Grant, only Ush $17.2 \mathrm{~m}$ was put to use. Ush $40 \mathrm{~m}$ was unaccounted for, another $178.5 \mathrm{~m}$ was reimbursed to the Ministry of 
Finance, and Ush $3.1 \mathrm{~m}$ was spent on bank charges (New vision, October 01, 2003)

There have been cases where education officials have been arrested for bribery when dealing with corruption cases.

The principal of Moroto Core Elementary Teachers College has been arrested for allegedly attempting to bribe officials from the Inspector General of Government to suppress a case. ... [together with the bursar they] attempted to bribe the officials with Ush 1 million. The duo was summoned by the IGG for several other allegations, concerning mismanagement of college funds and failure to give allowances to their tutors (Sunday Monitor, October 12, 2003, p. 4.).

Not all districts registered the activities for which the funds were utilized. (This is reflected in the district profiles). Some districts did account for the capacitybuilding funds (PAF report, April 2003).

Parliament has considered alternatives for decentralizing the selection, procurement and distribution of textbooks. In light of the rampant corruption and mismanagement at both the school and district level, parliament decided to maintain centralized textbook procurement (USAID, 2000). Corruption increases education expenses. It is distorting decision making processes and undermining social values. That it is happening in the education sector defeats the main purpose of education (UNESCO, 2004). Uganda could learn from countries such as Brazil which has set stricter definitions for corruption, improved administrative and control procedures through training, regional offices and manuals (UNESCO, 2004).

In addition to boosting accountability, participation procedures need to be strengthened (Suzuki, 2002). There is a need to check situations where perceived benefits to the communities and to marginalized districts and stakeholders have been captured by the already privileged. In a way devolution of responsibility is also a form of pushing resource burdens to lower levels. A worstcase scenario might arise years down the road, when local districts will be required to fund their public services. This would be a disaster for low revenuegenerating districts, which are in the majority in rural areas.

Even though international donor agencies encourage decentralization as a way of reducing the national debt, it is not evident that decentralization solves the problem of limited central financial resources. The generation of more resources at the local level faces management and resource base inadequacies. The local tax base is very small in many rural districts. In some old districts that have been split the revenue sources have dwindled as new districts sap the resource base of older districts.

\section{Political Risks}

Educational decentralization is complex and might be different from other forms of decentralization: it requires the will and strength of numerous systems, institutions and personnel. Educators might wish to work at a shared vision, including perceived out-comes and feared shortcomings of this reform at all levels, including the community level. Since the Ugandan decentralization 
initiative was part of a larger political move, there are likely pockets of passive resistance among the actors. With the numerous units and departments in the Ministry of Education, along with tiered local governance at lower levels, one hopes that reform initiatives will not be diluted at every level in Uganda as they were in Venezuela (Hanson, 1998). UNESCO (2004) underscored the need to raise awareness of administrative officials about the philosophy of decentralization. To encourage participation in reform initiatives the Ministry should ensure that this is a win-win situation at both the local and national levels. Transferring positive financial and non-financial opportunities to the districts and subsequent levels is key. Hanson (1998) has identified wide collaboration as a component of successful decentralization. The Uganda national government has not dumped financial and administrative burdens onto the districts as Argentina did (Hanson, 1998).

With decentralization, the government replaced Parent Teacher Associations (PTAs) with broader councils, School Management Committees (SMCs), which include members of the community. As was the case in Colombia, it was a political decision, not an educational one, to remove power from the PTA as an influential group that had started subsidizing teachers' salaries and other school expenses (UNESCO, 2004). As the PTA's power is removed, whether or not the local community will rise up to participate in the SMCs depends on the appointment procedures, level of establishment of the school and whether it is a boarding school or a private school. Although disempowering PTAs appears to be a way of keeping a balance between parental and community participation, many villages contain schools in which their children cannot afford to enroll. SMC committees might therefore not have any representation from parents of students at such schools.

Councilors are elected positions in all five tiers. The President reshuffles the cabinet regularly. In countries where this is the case, it has been observed that the planning and implementation of decentralization is disrupted by the constant top-level personnel changes. In Uganda the Minister of Education and the state ministers at different levels of education have all regularly been reshuffled. Toplevel policy makers in education are usually not educators by profession.

In the transition period from centralized to decentralized education delivery, clarity over roles and responsibilities has been a problem. This has been especially so between the CAO, DEO, and Local Councils at lower levels. Consider that some district staff such as the district assistant engineer report directly to the Ministry of Education and Sports whereas others report to the CAO. There is also an uncertain relationship between staff of the Teacher Development and Management System (TDMS) and the DEO. This lack of clarity at the TDMS may not facilitate the tailoring of personnel training to the needs of the district. The responsibility of the Coordinating Center Tutor (CCT) at the district has come into question: some DEOs want the tutor to report to the district administrative office rather than to the Elementary Teacher College (PTC). Overlapping responsibilities and role conflicts characterize decentralization of education in Cameroon and Colombia as well (UNESCO, 2004). More explicit defining and some revising are needed to eliminate confusion about responsibilities for 
reporting, management and accountability.

There is a concern that over-proliferation of conditional grants is not promoting good governance and has a negative impact on service delivery. The conditional grant for construction (SFG) functions reasonably well, but it has an unclear relationship with the Local Government Act. The UPE capitation grant suffers from serious delays at the district level, and from non-compliance with administrative guidelines (USAID, 2000). Guidelines for both grants are seen as excessively rigid. A number of reforms have been directly affected by decentralization.

\section{Decentralization as an Educational Reform: A Way Forward}

Given Uganda's background of political and economic instability, and the continued instabilities in some areas of the country, a balance between national crisis and political stability is a factor in the success of decentralization. One hopes that with any change of governance, the next political leaders will have the will to evaluate the successes and failures of the decentralization reform initiative.

Decentralizing the education system in Uganda makes sense as a politically motivated development. Quantitative benefits are evident. Decentralization has led to increased enrollment and resource flow at the elementary level. Educators need to determine how to maximize the benefits of the process. More infrastructure and analyses need to be put in place to ensure that the perceived benefits such as increased diversity and community participation are realized. It is in this way that educationalists will turn this political and economic agenda into a curricular reform.

Educational leaders and personnel at the various levels will continue to be challenged by the implementation of decentralization. There is a need to work through the conceptualization of decentralizing education, to identify and eliminate impediments to its effectiveness. There is need to reflect on the inherent risks of decentralizing much less privatizing important services such as education. Although it might be the case that delivery of feeder roads as a basic service is facilitated by decentralizing governance, education service delivery is much more complex.

Improvement in the quality of education has been slow. This is evidenced by minimal changes in curriculum taught. Declining quality in education has already deterred affluent parents from keeping children in public schools. Educators could focus on qualitative indicators such as relevance of education curricula, increased productivity of school graduates, increased retention rates and literacy rates (Deininger, 2003; McGee, 2000).

Resources have been assigned to basic education to the detriment of other levels and other public services as is the case in Morocco (UNESCO, 2004). In Uganda decentralization has been reduced to districtization and as such blocked development at the lower levels (UNESCO, 2004). In the new organization structure there appears to be a void between the schools and the district level that could usefully be filled by an equivalence of an educational board, a group of schools. Boards would have a better capacity to interact and negotiate with the districts governments than individual schools. 
The conception that decentralization would eliminate what it saw as unnecessary bureaucratic channels and reduce corruption by minimizing the number of centralized office levels to be consulted was mistaken. It is still too early to determine whether the goals of boosting the level of monitoring; the goal of managing school according to local priorities; the goal of improving financial accountability; and the goal of raising local revenue to fund services have been achieved.

Many criteria for successful decentralization would reveal that Uganda was not ready for decentralization. The central government was not yet stable especially as regards to resolving military conflicts in the North and East. Many local authorities were not yet able to assume administrative and financial responsibilities (UNESCO, 2004). However, the stable macroeconomic environment; priority for education, political will, robust budget processes, and the interest of multilateral donor agencies in decentralization (Murphy, 2005; UNESCO, 2004) were central in the implementation of decentralization.

Decentralizing education raises questions some of which are unique to developing countries. With the population size of Uganda close to 30 million people (See Table 1; FAO, 2005) decentralizing governance seems helpful. However the size of the country in terms of area and GNP does not appear to warrant regional and economic decentralization. To perceive decentralization as a blanket panacea to problems of political and economic instability is mistaken.

\section{Acronyms}

$\begin{array}{ll}\text { CAO } & \text { Chief Administrative Officer } \\ \text { CC } & \text { Coordinating Center } \\ \text { CCT } & \text { Coordinating Center Tutor } \\ \text { CAO } & \text { Chief Administrative Officer } \\ \text { DECBP } & \text { District Education Capacity Building Programme } \\ \text { DEO } & \text { District Education Officer } \\ \text { DIS } & \text { District Inspector of Schools } \\ \text { EMIS } & \text { Education Management Information System } \\ \text { EPRC } & \text { Education Policy Review Commission } \\ \text { ESIP } & \text { Education Strategic Investment Plan } \\ \text { FAO } & \text { Food and Agriculture Organization } \\ \text { LC } & \text { Local Council } \\ \text { MoES } & \text { Ministry of Education and Sports, Uganda } \\ \text { MoFED } & \text { Ministry of Finance and Economic Development } \\ \text { MoLG } & \text { Ministry of Local Government } \\ \text { NCDC } & \text { National Curriculum Development Center } \\ \text { NRM } & \text { National Resistance Movement } \\ \text { PAF } & \text { Poverty Alleviation Fund } \\ \text { PTA } & \text { Parent Teacher Association } \\ \text { PTC } & \text { Primary Teacher College } \\ \text { TDMS } & \text { Teacher Development and Management System } \\ \text { SFG } & \text { School Facilities Grant }\end{array}$




$\begin{array}{ll}\text { SMC } & \text { School Management Committee } \\ \text { UNEB } & \text { Uganda National Examinations Board } \\ \text { UNESCO } & \text { United Nations Educational, Scientific and Cultural } \\ & \text { Organization } \\ \text { UPE } & \text { Universal Primary Education } \\ \text { USAID } & \text { US Agency for International Development } \\ \text { USE } & \text { Universal Secondary Education }\end{array}$

\section{Note:}

The current government is considering formally remunerating councilors at LC I and LC II levels.

\section{References}

Al-Samarrai, S. (2003). Financing primary education for all: public expenditure and education outcomes. in Africa. Journal of International Development, 18, 179206.

Bitamazire N. G. (2005). Status of Education for Rural People in Uganda. A presentation by the Minister of Education, Uganda at the Ministerial Seminar on Education for Rural People in Africa, Addis Ababa, Ethiopia.

Odaet, C. F. (1990). Implementing Educational Policies in Uganda World Bank Discussion Papers: Africa Technical Department Series. No. 89. Washington, DC: World Bank.

Deininger, K. (2003). Does cost of schooling affect enrollment by the poor? Universal Primary Education in Uganda. Economics of Education Review, 22 (3), 291-305.

FAO, Food and Agriculture Organization. (2005). Education for Rural People in Africa: Policy Lessons, Options and Priorities. Ministerial Seminar hosted by the Government of Ethiopia. Food and Agriculture Organization of the United Nations, Report by Marcelino Avila \& Lavinia Gasperini. Retrieved January 31, 2006, from http://www.fao.org/newsroom/common/ecg/107444/en/paper.pdf.

Gershberg, A. I., \& Winkler, D. (2003). Education decentralization in Africa: A review of recent policy and practice Retrieved January 31, 2006, from http://info.worldbank.org/etools/docs/voddocs/490/946/africa.doc.

Hanson, M. E. (1998). Strategies of educational decentralization: Key questions and core issues. Journal of Educational Administration, 36 (2), 111-128.

Heynman, P. S (1983). Education during the period of austerity: Ugandan, 1971-1981. Comparative Education Review, 27(3), 403-413.

IDB, Inter-American Development Bank (2000). Reforming Elementary and Secondary Education in Latin America and the Caribbean: An IDB Strategy. Sustainable Development Department. Sector Strategy and Policy Papers Series. Washington, D.C: Inter-American Development Bank. 
Ssekamwa, J. C., \& Lugumba, S. M. E. (1973). Education development and administration in Uganda 1900- 1970. Kampala: Longman's Limited.

McGee, R. (2000). Meeting the International Poverty Targets in Uganda: Halving Poverty and Achieving Universal Primary Education. Development Policy Review, 18(1) pp. 85-106.

MoES (2006). Final Draft Report On A Case Study on the Impact of strengthening Planning, Management and Implementation on the Quality of Basic Education in Uganda.

MoES (2003, September). Draft report on a case study on the impact of UPE on the quality of basic education in Uganda, by Mulyalya, C., Arach, A., Nantume, O. \& Zalwango, C. Kampala, Uganda: MOES. Retrieved April 28, 2007 from http://www.education.go.ug/upe.htm

MoES (2003, August). Monitoring District Implementation of Programmes Under Poverty Action Fund (PAF). In The Education Sector. A Report on the Monitoring Exercise Carried Out In 23 Districts And 13 Municipalities, April - August 2003. Retrieved January 31, 2006, from

http://www.education.go.ug/PAF\%20Report\%20(Aug\%202003).doc.

MoES (2003, May). Final Draft Report On A Case Study on the Impact of TDMS on the quality of Basic Education in Uganda. Retrieved January 31, 2006, from http://www.education.go.ug/tdms1.htm.

MoES (2003, April). Final Report on Monitoring and Evaluation of PAF Programmes, in 30 Districts of Eastern And Central Uganda. Retrieved January 31, 2006, from http://www.education.go.ug/PAF\%20Report.htm.

http://www.education.go.ug/planning,_management_and_implementation.htm.

MoES (2001, May). The development of education in Uganda in the last ten years. Report on the Development of Education for the 46th Session of the International Conference on Education, Geneva, Switzerland. Retrieved April 28, 2007 http://www.ibe.unesco.org/international/ICE/natrap/Uganda.pdf.

MoES (1998). Education Strategic Investment Plan 1998-2003. Retrieved January 31, 2006, from:

http://www.usaid.or.ug/SO8\%20annexes/Education\%20Sector\%20Investment\% 20Plan\%20(ESIP)\%20-1998-2003.doc

Murphy, P. (2005). Education, educators and financing modalities: reflections on experience in Uganda. Journal of International Development, 17(1) pp.131- 47.

Mushemeza, D. E. (2003). Financial Management of Education in a Decentralized Setting: The Case of Uganda. A paper prepared for CODESRIA - Working Group on Finance and Education (WGFE).

Naidoo, J. P. (2002, March). Education decentralization in sub-Saharan Africa-espoused theories and theories in use. Presented at CIES Annual Conference, University of Central Florida. ED472263.

Odaet, C. F. (1990). Implementing Educational Policies in Uganda World Bank Discussion Papers: Africa Technical Department Series. No. 89. Washington, DC: World Bank, 29pp.

Paige, J. R. (2000). Preserving order amid chaos: The survival of schools in Uganda, 1971-1986. Berghan Books.

Royal Netherlands Embassy (2003). Uganda: The fight against corruption. A case study on the prevalence of corruption in Uganda, specifically in local government, education, justice, law \& order, and procurement. Kampala, Uganda, Report by Sandra Zwart. Retrieved January 31, 2006, from

Education canadienne et internationale Vol. $36 \mathrm{n}^{\mathrm{o}} 1$-juin 2007115 
http://www.u4.no/document/showdoc.cfm?id=94.

Saito, F. (2000). Decentralization for participatory development in Uganda: Limitations and prospects. Journal of Intercultural Communication, Ryukoku University. Retrieved December 9, 2005, from http://www.world.ryukoku.ac.jp/ fumisait/en/jic2000.pdf.

Ssekamwa, J.C., (1997). History and development of education in Uganda. Kampala: Fountain Publishers Ltd.

Ssekamwa, J. C., \& Lugumba, S. M. E. (1973). Education development and administration in Uganda 1900- 1970. Kampala: Longman's Limited.

Stasavage, D. (2005). The role of democracy in Uganda's move to universal primary education. Journal of Modern African Studies, 43(1), 53-73.

Steiner, S. (2006). Decentralisation in Uganda: Exploring the Constraints for Poverty Reduction. Working papers of GIGA Research Programme: Transformation in the Process of Globalisation. Working papers of GIGA, $\mathrm{N}^{\circ} 31$, November. Retrieved April 28, 2007, from http://www.giga-hamburg.de/content/publikationen/pdf/wp31_steiner.pdf. Summary at http://www.education.go.ug/strategicPlan.htm.

Suzuiki, I. (2002). Parental participation and accountability in primary schools in Uganda. Compare, 32 (2), 243-259.

Smyth, J. (1970). The Political Economy of Educational Planning in Uganda. Comparative Education Review, 14(3), 350-362.

Republic of Uganda (1997). The Local Government Act.

UNESCO (2004). Formula funding of schools, decentralization and corruption: a comparative analysis. Paris: IIEP

USAID (2000). Support to Uganda Primary Education Reform: Final Report. The Basic Education and Policy Support (BEPS) Activity. Jeanne Moulton. Retrieved December 9, 2005, from http://www.beps.net/publications/SUPPORT\%20TO\%20UGANDA\%20PRIMA RY\%20EDUCATION\%20REFORM.pdf

Wamala, P. (2004). Decentralization and its effect on education service delivery in Uganda. A case study of Mpigi district 1993.

Immaculate Namukasa is an Assistant Professor in mathematics education. Her current research interests are in Students' mathematical thinking, Teaching for understanding, Phenomenology of attending and knowing Globalization and education, Complexity research. She can be reached at inamukas@uwo.ca.

Ronald Buye is an MA candidate in Ethics and Public Management at Makerene University, Uganda. His interest is in Development related issues. He can be reached at buyeronald@yahoo.co.uk . 